\title{
EU REGIONAL POLICY SUPPORT FOR RURAL LOCAL DEVELOPMENT IN EASTERN POLAND
}

\author{
Joanna Rakowska ${ }^{1}$, PhD \\ ${ }^{1}$ Warsaw University of Life Sciences - SGGW
}

\begin{abstract}
The aim of the study was to investigate if the rural communes of Eastern Poland, which is the poorest macro-region of Poland and one of the poorest of the EU, benefited from EU regional policy as much as other rural communes in the country. Based on the secondary data from the Ministry of Regional Development, Central Statistical Office and National Court Register the total amounts of EU funding absorbed by these communes as well as Rscr index were calculated. Communes were categorised based on the absorption value, which made a tool for comparative analysis. The findings proved that on average rural communes of Eastern Poland benefited from EU regional policy funding more than other rural communes in the country. However, there were significant differences between and within rural areas of NUTS 2 regions forming Eastern Poland, which can be an indication for amending regional policy as a tool supporting rural areas lagging behind in social and economic development.
\end{abstract}

Key words: EU regional policy, rural areas, Eastern Poland.

JEL code: R00.

\section{Introduction}

The European Union cohesion and regional policies were established to reduce structural disparities resulting from economic, social and territorial imbalances among regions (My Region ..., 2017). As there are not only significant inequalities among regions, but many regions also experience considerable internal development disparities between and within urban and rural areas, the EU regional and cohesion policies support local development. And so they aim at supporting endogenous development, identified with bottom-up development and has long been recognised as a special form of regional development (Coffey and Polese, 1984; Ploeg and Long, 1994; Lowe et al., 1995).

Structural funds, which have been the main measures of implementing these policies have generally been addressed to NUTS 2 regions lagging behind in social and economic development, i.e. those whose GDP per capita has been lower than $75 \%$ of the average EU GDP per capita. Since Poland's accession to the EU in 2004, all 16 Polish NUTS 2 regions have met this basic criterion and qualified for EU regional policy assistance. The very low GDP per capita in five of Polish regions of Eastern Poland, i.e. Warminsko-Mazurskie, Podlaskie, Lubelskie, Swietokrzyskie and Podkarpackie (fig. 3) has classified them amongst the poorest regions in the $\mathrm{EU}^{2}$.

Due to its social and economic situation Poland has been the biggest beneficiary of EU regional policy funding since the budget perspective of 2007-2013. EU structural funds 2007-2013 were allocated in Poland under four nationwide operational programmes (OPs), i.e. Infrastructure and Environment OP (IENOP), Human Capital OP (HCOP), Innovative Economy OP (IECP), Technical Assistance OP (TAOP), under one multiregional Development of Eastern Poland OP3 (DEPOP), and 16 Regional Operational Programmes. EU regional policy funding from operational programmes 20072013 was available to a wide range of beneficiaries, including local self-governments who are the most important actors of endogenous sustainable local development. Their role in this process is determined by the current legal regulations [Law of March 8, 1990; Law of 24 July, 1998) and from international agreements (UN 1992; ONZ 2012; UN 2015). In practice, the role of local selfgovernment in supporting local rural development is significantly limited by financial restraints

\footnotetext{
${ }^{1}$ Corresponding author. Tel.: +48 22 5934076, E-mail address: joanna_rakowska@sggw.pl

2 The division of Poland into the richer Western regions and poorer Eastern region is also confirmed by findings of other analysis (WojewodzkaWiewiorska and Dudek, 2016).

${ }^{3}$ The multiregional Operational Programme Development of Eastern Poland (DEPOP) was addressed solely to the five above mentioned poorest regions of Poland, but it aimed mainly at supporting the development of urban areas.
} 
(Kolodziejczyk, 2001). Operational programmes providing a non-repayable financial support to a wide range of investment projects were to lessen this key development barrier especially in regions lagging behind in social and economic development, such as Eastern Poland. However, to obtain EU funding rural self-governments of Eastern Poland had to compete with urban and rural beneficiaries from all over the country under nationwide OPs and with beneficiaries from their regions under regional OPs, which were Lubelskie ROP, Podkarpackie ROP, Podlaskie ROP, Swietokrzyskie ROP, Warminsko-Mazurskie ROP. As all beneficiaries had to co-finance EU supported projects from domestic sources, the rural self-governments of the five poorest regions in the country, might have been less successful in obtaining financial assistance from this source. So the hypothesis set for this paper is: rural areas of Eastern Poland benefited from EU regional policy support less than rural areas in other regions of the country.

To verify this hypothesis, the aims of this elaboration were: (1) to define how much rural local self-governments of Eastern Poland absorbed from Operational Programmes 2007-2013, (2) to compare the outcomes with absorption of EU funding by other rural communes in the country, (3) to define the budgetary significance of the absorbed EU funding.

\section{The applied research methods}

The study was carried out based on data concerning all projects carried out by rural communes in Poland under operational programmes 2007-2013. Rural communes were defined according to the latest version of DEGURBA classification. The quantitative secondary data was obtained from the National Information System (SIMIK), the Ministry of Regional Development, which has been the Polish implementing agency for operational programmes and the Central Statistical Office of Poland, Local Data Bank. As the implementation of operational programmes 2007-2013 ended on 31 December, 2015, the data set includes information on 14754 projects carried out by $1870^{1}$ rural communes in Poland as of December 2015. The SIMIK dataset was verified with the data from the National Court Register. The verified SIMIK data enabled further calculation of:

- the value of EU funding obtained by each rural commune in Poland, and next:

- the differences $(D 1)$ between the value of EU funding obtained by rural communes in Eastern Poland $\left(V_{R C E P}\right)$ and the average value of EU funding obtained by all rural communes in the country $\left(A V_{R C C}\right)$ :

$$
D 1=V_{R C C}-V_{R C E P}
$$

Based on the above results on the average absorption per 1 rural commune in the country as a threshold value, the rural communes were categorised into 4 classes:

- class 1: the communes that absorbed less than $50 \%$ of the average EU funding per one rural commune in the country;

- class 2: the communes that absorbed from $50 \%$ up to $100 \%$ of the average EU funding per one rural commune in the country;

- class 3: the communes that absorbed from $100 \%$ up to $150 \%$ of the average EU funding per one rural commune in the country;

- class 4: the communes that absorbed $150 \%$ and more of the average EU funding per one rural commune in the country. 
The study also looks into the quantitative significance of EU funds for communes in the years 2007-2013, which was defined based on the relation of the sum of EU co-financing obtained from all OPs 2007-2013 to the average annual revenues of commune budgets in the analysed years (Rscr index, based on the formula: $R s c r=\frac{\sum_{i=2007}^{2015} f u_{i}}{\left(\sum_{i=2007}^{2015} b r_{i}\right) / n} \times 100 \%$ where:

$\mathrm{fu}_{\mathrm{i}}$ - total EU funding obtained from operational programmes 2007-2013, in PLN,

$\mathrm{br}_{\mathrm{i}}$ - total budget revenues of LAU 2 in a given year, in PLN,

$\mathrm{n}$ - number of years (9) of the real time of implementation of OPs 2007-2013, i.e. from 2007 to $2015^{1}$.

The aim of the research was also to check whether there is a correlation between the obtained EU funding and the two most important endogenous development factors such, i.e. population and the total budget revenues of the communes. The population was taken into consideration as a factor generating developmental needs, while budget revenues can determine communes' capability to cofinance the projects from domestic sources, as required by EU regional policy principles.

The aim of the research was also to check whether there is a correlation between the obtained EU funding and the two most important endogenous development factors such, i.e. population and the total budget revenues of the communes. The population was taken into consideration as a factor generating developmental needs, while budget revenues can determine communes' capability to cofinance the projects from domestic sources, as required by EU regional policy principles.

The novelty and topicality of the research.

The EU budget perspective 2007-2013 was the first one in which Poland participated from the beginning till its end, and so the results of implementing operational programmes 2007-2013 make the first and so far the only ${ }^{2}$ complete basis for studies on the effects of EU funding absorption by different groups of beneficiaries in the country. A wide range of beneficiaries of operational programmes 2007-2013 included local self-governments, who are not only the most important actors of endogenous sustainable local development, but they are also the group of beneficiaries who absorbed the biggest share of EU funding under operational programmes 2007-2013 (Rakowska, 2016). Although there were numerous studies on different aspects of EU funding absorption (Poweska, 2018; Poweska 2016; Pomianek and Drejerska 2016), it has not been investigated so far how much all rural communes of Eastern Poland, the poorest macro-region in the country, benefited from this source and how this absorption differed from the absorption by other rural communes in the country.

The findings can be helpful in taking decisions on either continuing so far system of allocation of EU funding in Poland or on changing it, e.g. by addressing more funds to rural local units lagging behind in social and economic development. Thus the study can contribute to the realisation of evidence- and place-based EU (Barca, 2009) and domestic regional policy.

\section{Research results and discussion}

Eastern Poland includes 709 communes (LAU 2), of which 595 (84\%) are defined by Degurba classification criteria as rural. All these rural communes were beneficiaries of operational programmes 2007-2013. They absorbed $4115.14 \mathrm{mln}$ PLN. As much as $70 \%$ of this sum came from Regional

${ }^{1}$ According to EU regional policy rule ' $n+2$ '.

2 As Poland participated in the budget perspective 2000-2006 partly, since the accession on May 1, 2004, and the implementation of operational programmes 2014-2020 of the on-going budget perspective will end and provide complete data on December 31, 2022. 
Operational Programmes (ROP) of the 5 voivodships forming this macro region, $23 \%$ from Human Capital OP (HCOP) and only $4 \%$ and $3 \%$ from Innovative Economy OP (IECOP) and Infrastructure and Environment OP (IENOP). The structure of EU funding absorbed by rural communes of Eastern Poland was quite similar to the structure of EU funding absorbed by other rural communes in the country (fig. 2). The very small share of funding absorbed in both cases from Innovative Economy OP (IECOP) and Infrastructure and Environment OP (IENOP) proves, that the principles of these programmes assuming realisation of big investments were not favourable to rural communes. The Operational Programme Development of Eastern Poland appeared to be the source of the smallest financial EU assistance to rural communes, which results from the fact that it was addressed mainly to urban communes.

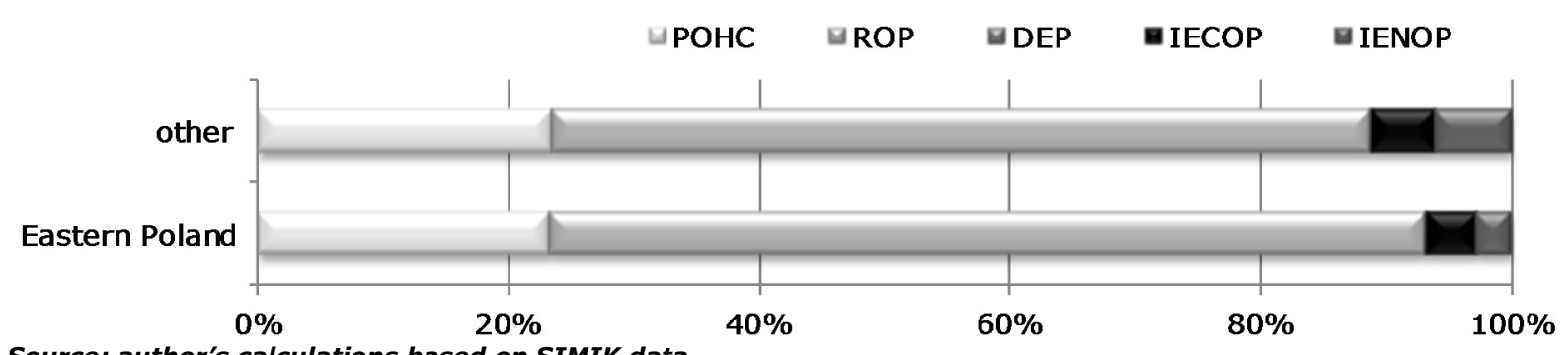

Source: author's calculations based on SIMIK data.

Fig. 1. The structure of EU funding absorbed by rural communes of Eastern Poland and in rest of the country by operational programmes 2007-2013

The regional operational programmes were a new tool of EU regional policy, introduced in member states in budget perspective of 2007-2013 for the first time. They were adjusted to different development needs of individual NUTS 2 regions, in Poland called voivodships. The results show that regional operational programmes were the main source of EU funding for rural communes of Eastern Poland. That proves that the aims of these 5 regional programmes were well-adjusted to the needs of rural areas, and that the rules of obtaining EU funding from this source were more favourable to rural communes than from nationwide operational programmes. Moreover, the competition for EU funding from regional programmes was limited to potential beneficiaries only from the given region, which for rural communes was another favourable condition. Only Human Capital Operational Programme stands out in the group of nationwide programmes, as it was a source of more than $20 \%$ of total EU funding absorbed both by rural communes of Eastern Poland and by rural communes in the rest of the country. This programme offered the possibility of EU co-funding for smaller projects, which at the same time require smaller sums of domestic co-funding, affordable to rural communes.

Projects carried out by rural communes under five Regional Operational Programmes were only hard ones, resulting in construction, modernisation or extension of different elements of technical and social infrastructure. Projects carried out by rural communes under Humane Capital OP were mostly soft ones, including trainings, educational activities for children and the youth as well as organisation of numerous cultural and sports events. The hard projects were mostly related with modernisation or equipping the local educational infrastructure, rather rarely with building new or extending already existing kindergarten or school buildings.

The total sums of EU funding obtained by rural communes in Eastern Poland were moderately correlated with their population (Pearson's $r_{x y}=0.509, p<0.000, \alpha=0.05$ ). The sums of EU funding obtained by rural communes in this macro-region were also moderately correlated with their average annual total revenues for 2007-2013 (Pearson's $r_{x y}=0.576, p<0.000, \alpha=0.05$ ). Bothe the results 
indicate that neither the population, nor the budget revenues were a very significant factor influencing absorption of EU funding by rural communes of Eastern Poland.

To verify the hypothesis that rural areas of Eastern Poland benefited from EU regional policy support less than rural areas in other regions of the country, the rural communes of Eastern Poland were categorised into four classes based on the amount of EU funding absorbed by them and referred to the average of EU funding absorbed by all rural communes in Poland. As the average of EU funding 2007-2013 per one rural commune in Poland appeared to be equal $6.12 \mathrm{mln}$ PLN, it made the threshold for defining the following classes:

- class 1: the communes that absorbed less than $50 \%$ of the average EU funding per one rural commune in the country, i.e. less than $3.06 \mathrm{mln}$ PLN;

- class 2: the communes that absorbed from $50 \%$ up to $100 \%$ of the average EU funding per one rural commune in the country, i.e. from 3.06 to $6.12 \mathrm{mln}$ PLN;

- class 3: the communes that absorbed from $100 \%$ up to $150 \%$ of the average EU funding per one rural commune in the country, i.e. from 6.12 to $9.17 \mathrm{mln}$ PLN;

- class 4: the communes that absorbed $150 \%$ and more of the average EU funding per one rural commune in the country, i.e. more than $9.17 \mathrm{mln}$ PLN.

The findings show that $41 \%$ of rural communes of Eastern Poland absorbed EU funding of a higher value than the national average for rural communes, while only $29 \%$ of rural communes in the rest of the country achieved this level. The subgroup including classes 1 and 2 also had a better layout in case of rural communes of Eastern Poland: $35 \%$ of this units achieved the lowest level of EU co-funding, while in the rest of the country this group included $51 \%$ of rural communes.

rural communes of Eastern Poland

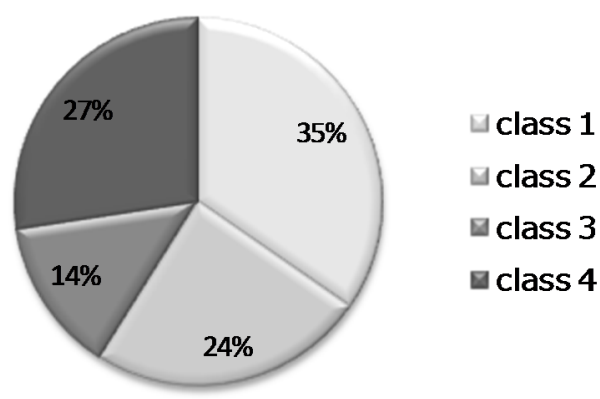

other rural communes

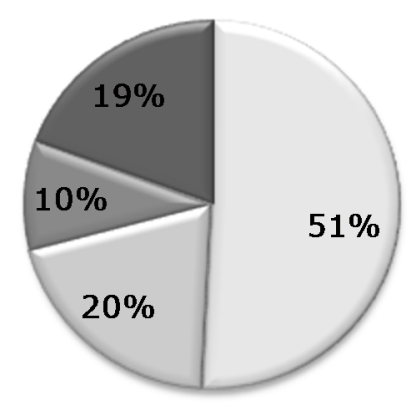

\section{Source: author's calculations based on SIMIK data}

Fig. 2. The structure of rural communes in Eastern Poland and the rest of the country by classes of absorption of EU funding

The above discussed findings lead to the question whether there are differences between rural communes of NUTS 2 regions within Eastern Poland. The spatial differentiation of rural communes by classes of EU funding absorption is quite significant, as shown in Fig. 3. The best absorption level was achieved by rural communes of Swietokrzyskie voivodship, where $84 \%$ of them absorbed more EU funding than the national average for rural communes. The second best was Podkarpackie, where $51 \%$ of rural communes absorbed more than the national average of EU funding per rural commune. Only $39 \%$ of rural communes of Lubelskie voivodship absorbed more than the national average. The poorest results were achieved by rural communes of Warminsko-Mazurskie and Podlaskie, where not only the share of rural communes above the national average was small (correspondingly $29 \%$ and $16 \%)$, but also the share of the communes in the lowest class 1 of EU funding absorption was very high (correspondingly $35 \%$ and $59 \%$ ). 
The above presented findings prove that there are significant differences in EU funding absorption among rural communes of individual voivodships of Eastern Poland. There are also significant differences within two voivodships, i.e. Lubelskie and Warminsko-Mazurskie, while Swietokrzyskie and Podkarpackie are relatively unified towards high absorption levels and Podlaskie is relatively unified towards low absorption levels by rural communes.
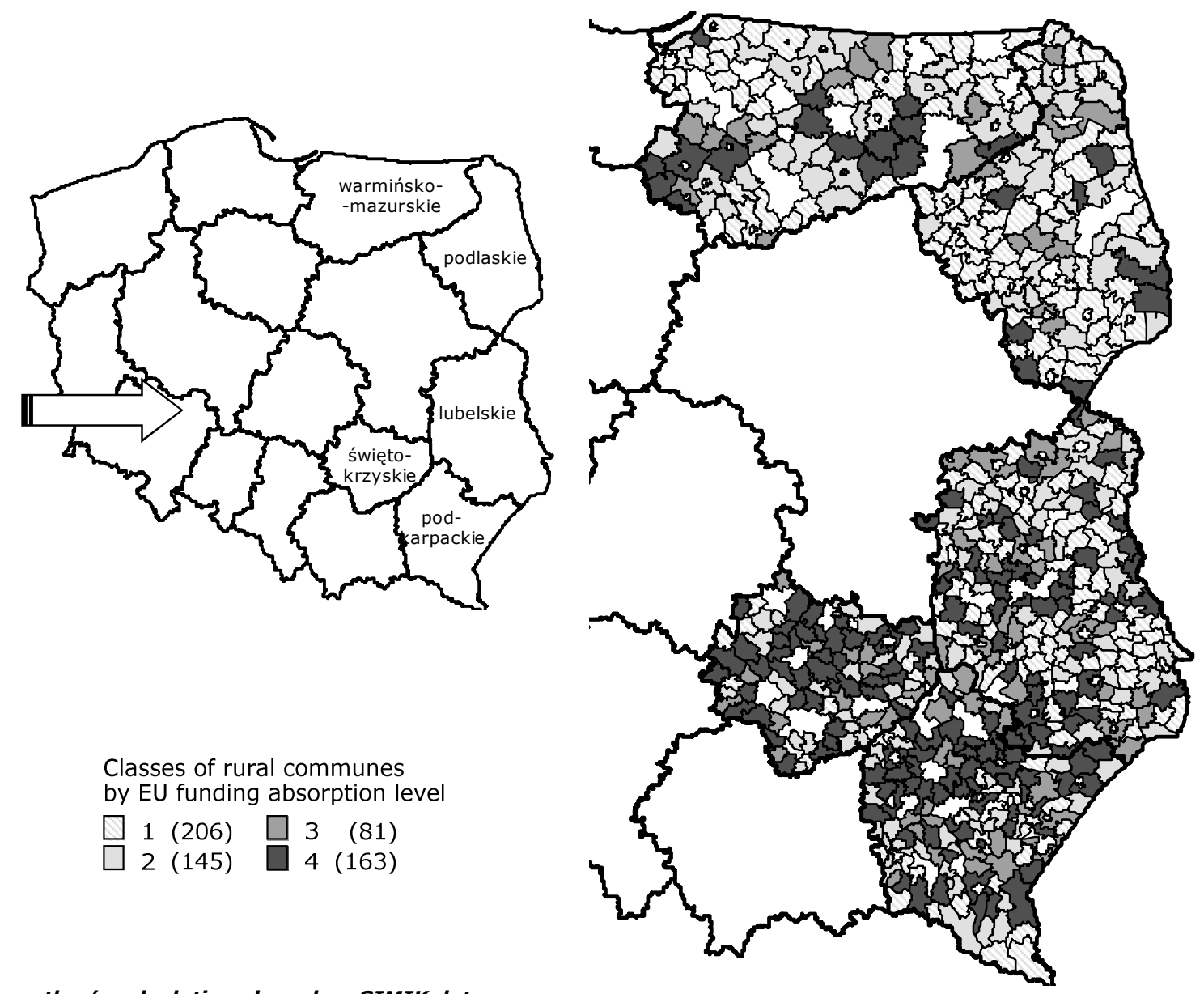

Source: author's calculations based on SIMIK data

Fig. 3. Spatial differentiation of classes of by rural communes in Eastern Poland by the level of EU funding absorption

Based on the Rscr index, the EU funding absorbed by rural communes of Eastern Poland made from $0.3 \%$ up to $175 \%$ of their average annual total budget revenues for 2007-2013. For 96 studied communes obtained EU funding made less than $10 \%$ of average annual total budget revenues, while for 21 Rscr was higher than $100 \%$. Other rural communes of this macro-region are characterised by Rscr within these brackets.

The correlation between the Rscr index value and the classes of rural communes by the absorption level was strong (Pearson's $r_{x y}=0.725, p<0.000, \alpha=0.05$ ).

\section{Conclusions and recommendations}

The above presented findings lead to the following conclusions.

1) Rural communes of Eastern Poland benefitted from the EU regional policy funding on average more than other rural communes in the country.

2) The budgetary significance of the absorbed EU funding for very different for individual rural communes, as it varied from $0.3 \%$ up to $175 \%$ of their average annual total budget revenues for 2007-2013. 
3) On the local level there are significant differences in the absorption of EU funding between and within rural areas of NUTS 2 regions of Eastern Poland.

4) The value of EU funding absorbed by rural communes of Eastern Poland was not significantly correlated with such endogenous factors as population or budget revenues.

5) Regional Operational Programmes and Human Capital OP were the main sources of EU funding for rural communes of this macro-region, which indicates what aims of programmes and what rules of granting EU co-funding are favourable to this group of communes.

6) As the budget perspective of 2014-2020 is still on-going, there is an urgent need to define the reason(s) for a very low absorption of EU funding by such large groups of rural communes in Podlaskie and Warminsko-Mazurskie voivodships and to investigate whether the rules and aims of Regional Operational Programmes for these NUTS 2 can be adjusted more to the absorption capacity of their rural communes.

\section{Bibliography}

1. Barca, F. (2009). An Agenda for Reformed Cohesion Policy. A Place-based Approach to Meeting European Union Challenges and Expectations, Report, Commission for Regional Policy.

2. Coffey, W.J., Polese, M. (1984). The Concept of Local Development: A Stages Model of Endogenous Regional Growth, Papers in Regional Science 55(1), pp. 1-12, doi.org/10.1111/j.1435-5597.1984.tb00823.x

3. Kolodziejczyk, D. (2001). Sytuacja finansowa gmin jako czynnik rozwoju lokalnego (Financial Situation of Communes as a Factor of Local Development), Samorzad Terytorialny, No 12, s. 38-60.

4. Lowe, P., Murdoch, J., Ward, N. (1995). Networks in Rural Development: beyond Exogenous and Endogenous Models [in:] J.D. van der Ploeg, G. an Dijk (eds.), Beyond Modernisation: The Impact of Endogenous Rural Development, Van Gorcum, Assen, European Perspectives on Rural Development Series.

5. My Region, My Europe, Our Future, Seventh Report on Economic, Social and Territorial Cohesion, European Commission, (2017), Brussles.

6. Ploeg, J.D. van, Broekhuizen, R. van, Brunori, G., Sonnino, R., Knickel, K., Tisenkopfs, T., Oostindie, H. (2008). Towards a New Theoretical Framework for Understanding Regional Rural Development [in:] Unfolding Webs: The Dynamics of Regional Rural Development [electronic document]

www.jandouwevanderploeg.com/2/EN/doc/Towards_new_theoretical_framework.pdf [accessed on 27.01.2013].

7. Pomianek, I., Drejerska, N. (2016). The Effects of Using Structural Funds at the Local Level - the Results of Qualitative Research among Project Beneficiaries, Management of Sustainable Development in Rural Areas: at Local and Regional Scales, eds. P. Borawski, I. Zuchowski, E.J. Szymanska, Ostrołeka: Wydawnictwo Wyzszej Szkoły Ekonomiczno-Spolecznej, pp. 75-85.

8. Poweska, H. (2016). Absorption of 2007-2015 EU Funding for Utilization of Cultural Assets in Rural Areas in Selected Voivodships of the Lowland Part of Poland, Rural Development and Entrepreneurship: Production and Co-operation in Agriculture: proceedings of the International Scientific Conference, 9-11 May 2018, Jelgava, Latvia, ed. Anita Auzina, Jelgava: Latvia University of Life Sciences and Technologies, pp. 259-266.

9. Poweska, H. (2018). Rural Areas of Poland as the Beneficiary of European Union Funding 2007-2013(15) for Cultural Projects, Economic Sciences for Agribusiness and Rural Economy: proceedings of the International Scientific Conference, Warsaw, 7-8 June 2018. T. 1, Warsaw, Warsaw University of Life Sciences Press, pp. 335-342.

10. Rakowska, J. (2016). Samorzady gmin jako beneficjenci polityki spojnosci Unii Europejskiej w latach 20072013 (2015) (Commune Self-governments as Beneficiaries of the EU Cohesion Policy 2007-2013 (2015)), Warsaw University of Life Sciences, Warsaw.

11. UN, 1992. Agenda 21. Action Programme, Rio de Janeiro.

12.UN, 2012. The Future We Want, accessed at http://www.unic.un.org.pl/rio20 on 31.08.2017.

13. UN, 2015. Transforming Our World: the 2030 Agenda for Sustainable Development, accessed at https://sustainabledevelopment.un.org/post2015/transformingourworld on 30.09.2016.

14. Ustawa z dnia 24 lipca 1998 r. o wprowadzeniu zasadniczego trojstopniowego podziału terytorialnego panstwa, Dz.U. 1998, nr 96, poz. 603 (Law of March 8, 1990 on the Introduction of the Primary Three-tier Territorial Division of the State, Journal of Law 1998, No 96, item 603).

15. Ustawa z dnia 8 marca 1990 r. o samorzadzie gminnym, Dz.U. 1990, nr 16, poz. 95 (Law of March 8, 1990 on Commune Self-government, Journal of Law 1990, No 16, item 95).

16. Wojewodzka-Wiewiorska, A., Dudek, H. (2016). Dynamics Of Rural Areas Development in Poland Convergence Analysis, Research for Rural Development, 2016, Vol. 2, pp. 99-105. 